DOI: $10.21608 / z v j z .2017 .29243$.

\title{
Occurrence of Avian Influenza Virus (H9 subtype) in Broiler and Layer Chickens at Sharkia Governorate
}

\author{
Hossam A.A. Gado ${ }^{1}$, Amal A.M. Eid ${ }^{2}$, Ibrahim A. Ghanem² ${ }^{2}$ and Mohamed K. Moursi ${ }^{3}$ \\ ${ }^{1}$ Reference Laboratory for Quality Control on Poultry Production (RLQP). Animal Health \\ Research Institute, Sharkia Branch, Egypt \\ ${ }^{2}$ Avian and Rabbit Medicine Department, Faculty of Veterinary Medicine, Zagazig University, \\ 44511, Egypt \\ ${ }^{3}$ Reference Laboratory for Quality Control on Poultry Production (RLQP), Animal Health \\ Research Institute, Ismailia Branch, Egypt
}

\begin{abstract}
Avian influenza (AI) is a contagious disease caused by type A influenza viruses. In spite of the mild nature of H9N2 low pathogenic AIV, the virus was isolated from frequent disease outbreaks with high mortality in different parts of the world. In this study, forty-two layer and broiler chicken farms (21/each) suspected to be infected with AIV of different breeds and ages during 2012 - 2014 were examined at Sharkia Governorate. The occurrence of AI in chickens using HI assay was $40.47 \%$. Subtyping for H9 and H5 subtypes has been done by specific antisera. The H9 was detected in $30.95 \%$ and H5 was $9.52 \%$. However, the occurrence of NDV in chickens was $23.80 \%$. The selected seven AIV isolates representing broiler and layer flocks were confirmed by rRT-PCR using primers and probes specific for Matrix gene, H9 gene, H5 gene and $\mathrm{H} 7$ gene. Seven isolates were positive for M. gene indicating AI virus detection, and then 6 out of 7 isolates were positive for $\mathrm{H} 9$ gene but negative for $\mathrm{H} 5$ and $\mathrm{H} 7$ genes. The last isolate was positive for $\mathrm{H} 5$ gene, negative for $\mathrm{H} 9$ and $\mathrm{H} 7$ genes. The phylogenetic analysis for $\mathrm{HA}$ gene of the Six H9 AIV isolates showed the placement of the Egyptian viruses within the same lineage of H9N2 viruses that circulated in the region with the parent strain (A/Quail/ Egypt/ $113413 \mathrm{v} / 2011$ ) of G1/97 lineage and other strains that circulating in the Middle East. The circulating H9N2 AIV genetic analysis is pointing to a minor evolution of H9N2 viruses. But at the same time the co-circulation of H5 \& H9 subtypes of AIV could be a risk for emergence of new AI viruses. Also, concurrent infection with viral (IBV and NDV) as well as bacterial agents (MG, Salmonella and E. coli) are considered the main cause behind increased mortality in H9N2 positive flocks.
\end{abstract}

Keywords: Avian influenza virus -Low pathogenic-H9-Sequencing.

\section{Introduction}

In Egypt, poultry industry is considered one of the most profitable in national income. Chickens are reared for both meat and egg production. Increased pathogen and concurrent infections threaten poultry production sector [1]. Avian influenza, Newcastle diseases and infectious bronchitis viruses and/ or bacterial agents (Mycoplasma, Salmonella and E.Coli) are commonly included in disease problems in both layer and broiler chickens [2].

AIV is an enveloped virus that belongs to the Orthomyxoviridae family and has an eightsegmented single-stranded negative sense RNA genome. Two pathotypes: highly pathogenic avian influenza (HPAI) viruses, which cause severe and fatal infections in chickens and low pathogenic avian influenza (LPAI) viruses, which are generally much less virulent in these birds. LPAI viruses can contain any haemagglutinin, but to date all HPAI viruses have contained either $\mathrm{H} 5$ or $\mathrm{H} 7$ [3]. The H9N2 avian influenza virus (AIV) was reported to be of low pathogenicity in chickens [4]. Infection with $\mathrm{H} 9 \mathrm{~N} 2$ viruses often result in decreasing of the laying rate of hens and co-infection with other viruses or bacteria which may cause severe morbidity and high mortality in chickens $[5,6]$.

In Egypt, while the HPAI H5N1 subtype circulating as endemic waves causing severe losses in poultry populations, the detection of H9N2 virus was reported in May 2011 that has been isolated from bobwhite quail [7], consequently Egypt has been endemic with H9N2 avian influenza virus and even circulated in H5N1 infected flocks [8]. 
The present study aimed to throw light on the occurrence of the LPAI H9 virus from different chicken breeds and ages at Sharkia Governorate and identification by HI and rRTPCR tests. Sequence analysis and phylogenetic tree of partial HA gene of H9 subtype were done.

\section{Material and Methods}

\section{Clinical, postmortem examination and Sampling}

Forty-two broiler and layer chicken flocks of different breeds and ages at Sharkia Governorate during 2012- 2014 were examined clinically. The postmortem examination was carried out and Samples were collected from twenty-one broiler flocks that experienced respiratory distresses and /or variable mortality rates beside twenty-one layer farms that suffered from drop in egg production and /or respiratory manifestations.

\section{Isolation and identification of AIVs}

Respiratory tissue pools (3 birds/each), tracheal and cloacal swabs were collected from birds for virus isolation. Samples were frozen at $-80^{\circ} \mathrm{C}$ until be examined. Commercial embryonated chicken eggs (ECE) of 9-11 dayold were inoculated via allantoic cavity route with $0.2 \mathrm{ml}$ of sample supernatant fluids [9]. The harvested allantoic fluids (AF) were screened by rapid hemagglutination (HA), quantitative $\mathrm{HA}$ and hemagglutination inhibition (HI) tests. These tests were performed according to WHO Manual on Animal Influenza Diagnosis and Surveillance and OIE for identification of AI isolates [10, 11], using specific antisera. Reference antigens and antisera specific for: $\mathrm{H} 5 \mathrm{~N} 1, \mathrm{H} 9 \mathrm{~N} 2$ and NDV were kindly supplied by Reference Laboratory for Veterinary Quality Control on Poultry Production (RLQP), Dokki, Giza, Egypt.

\section{Reverse transcriptase PCR for AIV-HA gene. Real-time}

RNA was extracted from positive HA and HI allantoic fluids using QIAamp Viral RNA Mini Kit (Qiagen, Valencia, Calif., USA). Cat. No. 52904. The procedure was performed according to the company's instructions

The Sequence of AI common primers \& probe used in real time PCR [12], $\left(5^{\prime}-3^{\prime}\right)$
Metabion (Germany). Sep1: AGA TGA GTC TTC TAA CCG AGG TCG, Sep2: TGC AAA AAC ATC TTC AAG TCT CTG, Sepro: 6FAM-5'-TCA GGC CCC CTC AAA GCC GA-3'-TAMRA. The Sequence of $\mathrm{H} 9$ primers $\&$ probe used in real time PCR [13], (5' - 3') Metabion (Germany), H9F: GGA AGA ATT AAT TAT TAT TGG TCG GTA C, H9R:GCC ACC TTT TTC AGT CTG ACA TT, H9PRO:6-CY5-5'-AAC CAG GCC AGA CAT TGC GAG TAA GAT CC-3'-TAMRA. The Sequence of $\mathrm{H} 5$ primers \& probe used in real time PCR [14], (5' - 3') Metabion (Germany). H5LH1: ACA TAT GAC TAC CCA CAR TAT TCA G, H5RH1: AGA CCA GCT AYC ATG ATT GC, H5 Probe: 6-FAM5'-TCW ACA GTG GCG AGT TCC CTA GCA- 3'-TAMRA. The Sequence of H7 primers \& probe used in real time PCR [15], (5' - 3') Metabion (Germany), LH6H7: GGC CAG TAT TAG AAA CAA CAC CTA TGA, RH4H7: GCC CCG AAG CTA AAC CAA AGT AT, H7 pro11:6-HEX-5'-CCG CTG CTT AGT TTG ACT GGG TCA ATC TBHQ- 3'. The reaction mix volumes for each reaction of the $\mathrm{M}, \mathrm{H} 9, \mathrm{H} 5$ and $\mathrm{H} 7$ genes of avian influenza virus were $10 \mu \mathrm{L}$ RNA template; $0.25 \mu \mathrm{L}$ for RT-enzyme $12.5 \mu \mathrm{L}$ for RT-PCR buffer; $0.5 \mu \mathrm{L}$ of each forward and reverse primers; $0.125 \mu \mathrm{L}$ for probe and 4.5 $\mu \mathrm{L}$ of RNase-free water. Thermocycling rRTPCR conditions for $\mathrm{H} 9$ and $\mathrm{M}$ genes were 50 ${ }^{\circ} \mathrm{C}$ for $30 \mathrm{~min}$, then $95^{\circ} \mathrm{C}$ for $15 \mathrm{~min}$, followed by 40 cycles at $95^{\circ} \mathrm{C}$ for $15 \mathrm{sec}$ then $45 \mathrm{sec}$ at $60^{\circ} \mathrm{C}$. While, $\mathrm{H} 5$ and $\mathrm{H} 7$ genes conditions were $50{ }^{\circ} \mathrm{C}$ for $30 \mathrm{~min}$, then $95{ }^{\circ} \mathrm{C}$ for $15 \mathrm{~min}$, followed by 40 cycles at $95^{\circ} \mathrm{C}$ for $15 \mathrm{sec}, 56^{\circ} \mathrm{C}$ for $30 \mathrm{sec}$ and $72{ }^{\circ} \mathrm{C}$ for $10 \mathrm{sec}$. PCR assays for IBV and Mycoplasma were done by biotechnology unit of RLQP. Bacterial isolation was done by bacteriology unit of RLQP Sharkia branch.

\section{HA gene sequencing}

Reverse transcriptase (RT)-PCR was used for HA gene amplification using specific H9gene primers [13]. H9-F800 5'-TGG GAA TCT AAT TGC TCC ATG GTT TGG ACA - 3', H9-R1300 5'-TCA TCA ATC TTG TTA TTG ATC ATA- 3'. The reaction mix volumes for RT-PCR of the $\mathrm{H} 9$ gene were $5 \mu \mathrm{L}$ RNA template; $1 \mu \mathrm{L}$ for RT-enzyme, $12.5 \mu \mathrm{L}$ for RT-PCR buffer; 1ul of each forward and 
reverse primers; and $4.5 \mu \mathrm{L}$ of RNase-free water. Thermocycling RT-PCR condition for $\mathrm{H} 9$ gene was $50^{\circ} \mathrm{C}$ for $30 \mathrm{~min}$, then $95^{\circ} \mathrm{C}$ for $15 \mathrm{~min}$, followed by 40 cycles at $95^{\circ} \mathrm{C}$ for 30 $\mathrm{sec}, 56{ }^{\circ} \mathrm{C}$ for $45 \mathrm{sec}$ and $72{ }^{\circ} \mathrm{C}$ for $2 \mathrm{~min}$

Amplified RT-PCR products were purified using the PCR purification KitH QIAquick gel extraction kit (Qiagen Inc. Valencia CA), following the manufacturer's instructions and were then sent for sequencing by using an Applied Biosystems 3130 genetic analyzer (ABI, USA). A BLAST search was conducted (http://www.ncbi.nlm.nih.gov/BLAST).

Sequence comparisons and phylogenetic relationships through a bootstrap of 1000 trials were determined with the MEGA version 7 program using the ClustalWalignment algorithm [16]. Additionally, nucleotide and amino acid identities were determined using the MegAlign module of Lasergene DNAStar software (Madison, WI). The nucleotide sequences were submitted to GenBank with accession numbers KJ206089, KJ206086,
KJ206090， KJ20608， KJ206087 and KJ206088.

\section{Results}

\section{Clinical and PM findings}

The clinical signs of the examined broiler flocks included respiratory signs such as Coughing, tracheal rales, sneezing, and difficult breathing, swelling of periorbital tissues with conjunctivitis, nasal and ocular discharges with mortality rates ranged from $0.5 \%$ to $70 \%$. In affected layer flock, drop in egg production ranged from $30 \%$ to $70 \%$ with decrease in feed consumption. The postmortem findings of the examined broiler flocks revealed tracheitis, congestion of lungs, exudation and cast formation at the tracheal bifurcation and lower bronchi. Pericarditis, perihepatitis, peritonitis and air-sacculitis were also observed. However, examined layer flocks revealed congestion of ovarian follicles with egg-yolk peritonitis. Atrophied or ruptured ova were observed in some birds (Figure 1).

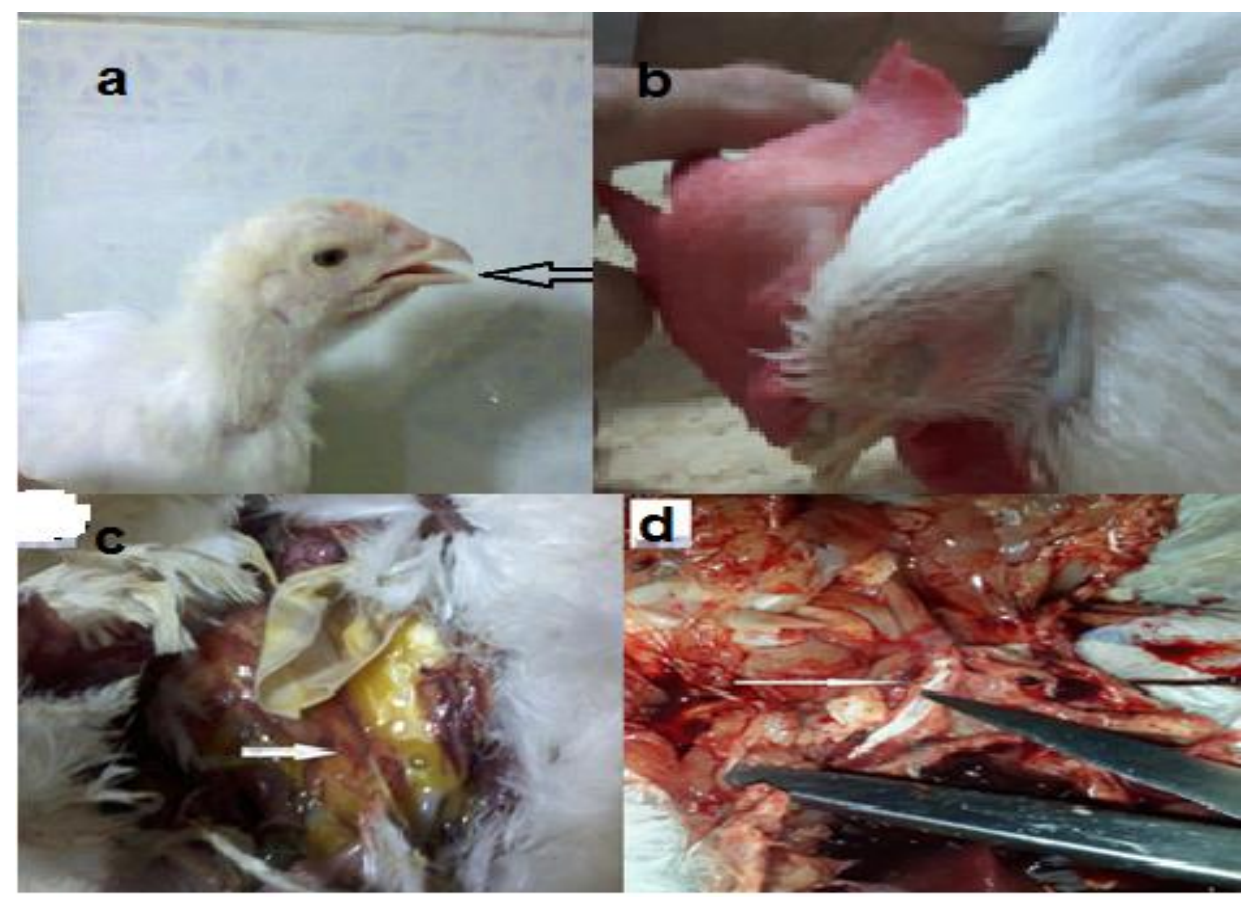

Figure 1: Clinical signs and gross lesions in chickens suspected to be naturally infected with $\mathrm{H9}$ a) A Broiler chicken 29 day-old naturally infected with H9AIV mixed with IBV showing gasping b) A commercial egg layer 196 day-old naturally infected with H9 AIV mixed with MG showing periorbital edema. c).A commercial egg layer 196 day-old naturally infected with H9 AIV mixed with MG displaying egg-yolk peritonitis d) A Broiler chicken 35 day-old naturally infected with H9AIV with CRD showing tubular cast formation occupied the bronchial lumen 


\section{Isolation and identification of AIVs}

The virus isolation trials revealed variable embryo lesions including congestion, petechial and diffuse hemorrhages and small embryos. Also, apparently embryos were observed. The harvested allantoic fluids were positive for HA in 26 out of 42 samples with a percentage of $61.90 \%$ which are quantified $\left(2^{5}-2^{9}\right)$ by plate HA test. The HI results revealed that; 13 were AI H9, $10 \mathrm{NDV}$ and 4 AI H5 with percentage $30.95 \%, 23.80$ and $9.52 \%$, respectively.

In broilers, AI virus was detected in 10 flocks out of 21 with a percentage $47.61 \%$, H9 and H5 subtypes were $38.09 \%$ and $9.52 \%$, respectively. Meanwhile, the NDV was $23.8 \%$.

Meanwhile, in layers, AI virus was detected in 7 flocks out of 21 with a percentage $33.33 \%$. The (H9 and H5) subtypes percentages were $23.8 \%$ and $9.52 \%$, respectively. On the other hand, NDV was detected in 5 flocks with a percentage $23.8 \%$. Mixed infection of H9 AIV and NDV was recorded in only one flock.

\section{Reverse transcriptase $R$ T-PCR results}

Real time RT- PCR was used to confirm results obtained by isolation, HA and HI tests and to determine type of HA gene. The seven selected virus isolates were subjected to rRTPCR (Table 1). These isolates were tested for $\mathrm{M}$ gene, $\mathrm{H} 9$ gene, $\mathrm{H} 5$ gene and $\mathrm{H} 7$ gene. Six isolates were positive for $\mathrm{M}$ and $\mathrm{H} 9$ genes and one was positive for $\mathrm{M}$ and $\mathrm{H} 5$ genes. However, all isolates were negative for $\mathrm{H} 7$ gene.

The PCR results revealed the presence of IBV in two flocks (one single and the other was mixed with H9 AIV), MG in one flock mixed with H9 AIV. Bacterial isolation revealed the presence of Salmonella species in one flock and E. coli in two flocks.

Table 1: RRT- PCR results for Avian influenza viruses ( $M$ and $H$ genes)

\begin{tabular}{|c|c|c|c|c|c|c|c|c|c|c|}
\hline \multirow{2}{*}{$\begin{array}{l}\text { Sample } \\
\text { code no }\end{array}$} & \multirow[t]{2}{*}{ Locality } & \multirow{2}{*}{$\begin{array}{l}\text { Age } \\
\text { days }\end{array}$} & \multirow{2}{*}{$\begin{array}{c}\text { Production } \\
\text { type }\end{array}$} & \multicolumn{2}{|c|}{ M gene } & \multicolumn{2}{|c|}{ H9 gene } & \multicolumn{2}{|c|}{ H5 gene } & \multirow[t]{2}{*}{ H7 gene } \\
\hline & & & & Result & $\mathrm{CT}$ & Result & CT & Result & $\mathrm{CT}$ & \\
\hline 1 & Deyarb Negm & 196 & Layer & +ve & 11.9 & +ve & 15,4 & -ve & -ve & -ve \\
\hline 3 & Mashtool & 420 & Layer & + ve & 12,3 & +ve & 14,7 & -ve & -ve & -ve \\
\hline 7 & Mashtool & 33 & Broiler & +ve & 12,5 & + ve & 13.6 & -ve & -ve & -ve \\
\hline 15 & Belbis & 35 & Broiler & + ve & 12.00 & $+v e$ & 15.5 & -ve & -ve & -ve \\
\hline 38 & Menia ElKamh & 29 & Broiler & +ve & 12.2 & $+\mathrm{ve}$ & 14.1 & -ve & -ve & -ve \\
\hline 39 & Zagazig & 410 & Layer & +ve & 17.3 & +ve & 21.00 & -ve & -ve & -ve \\
\hline 42 & Meet-Kenana & 200 & Layer & +ve & 14.1 & -ve & -ve & +ve & 14.1 & -ve \\
\hline
\end{tabular}

Partial sequencing of HA gene of $\mathrm{H9}$ subtype virus isolates

Amplification of AI isolates using RT-PCR

Six different isolates were submitted for amplification using RT-PCR. The electrophoresis run applied on the PCR product using specific primers to the $\mathrm{H} 9$ gene showed the presence of specific DNA bands detectable by ethedium bromide in agarose gel (Figure 2) at the expected molecular weight $(500$ bp) proving the positivity of the suspected haemagglutinating samples for $\mathrm{H} 9$ gene of AIV type A. 


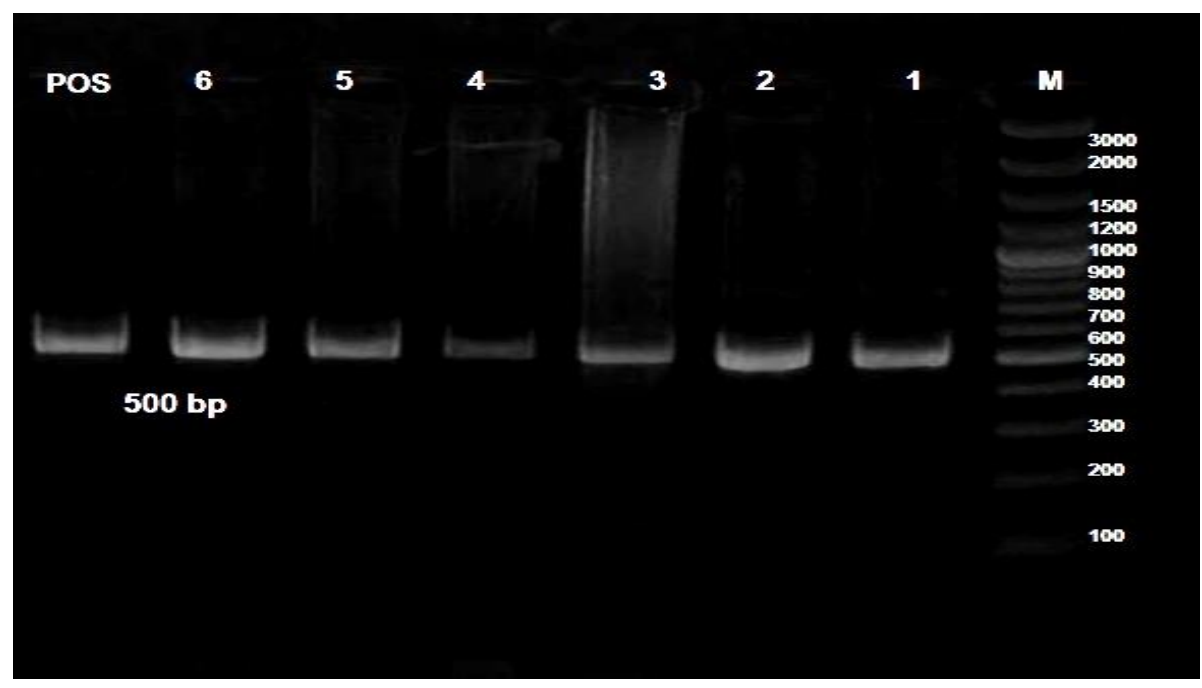

Figure 2: Agarose gel electrophoresis of the RT-PCR products of H9 gene. Lane M: marker 100 plus bp (1003000), lanes (1- 6) represents the tested samples with expected correct size 500 bp and positive control (V113413/2011) (Lane.7)

\section{Sequence analysis for HA gene}

Partial HA gene of six H9 viruses isolated at Sharkia Governorate between January 2012 and December 2012 was sequenced. All of these sequences have been submitted to the GenBank database. The nucleotide sequence of the six H9AIV isolates were aligned with some of selected H9AIVstrains from the blast data base of the Genbank (Figure 3).

The six isolates showed that they share 91.3 - $98 \%$ homology at nucleotide level. Identity with parent strain (A/Quail/ Egypt/ 113413v/2011) was 93.3-99.1\%. The percent of identity of six Egyptian H9 AIV isolates in our study was 90.5 - 99.7\% with Egyptian AI H9 AIV strains on gene bank (2011-2016).

Perpt igett

\begin{tabular}{|c|c|c|c|c|c|c|c|c|c|c|c|c|c|c|c|c|c|c|c|c|c|}
\hline & & 2 & 3 & 4 & 5 & 6 & 7 & 8 & 9 & 10 & 11 & 12 & 13 & 14 & 15 & 16 & 17 & 18 & 19 & 20 & \\
\hline 1 & & & & 0 & & 99.1 & 983 & 99.4 & 92.1 & 1 & & & 3.3 & 85 & 662 & 10 & 90.4 & 86.6 & 90.4 & 68 & 1 \\
\hline 2 & & & & & 9 & & 8 & 80 & 7.7 & 7 & & & & & & & & & 39 & & 2 \\
\hline 3 & & & & & & 39 & 2.1 & 939 & 936 & 936 & & & & 24 & 0.4 & & & 19 & 5.7 & & 3 \\
\hline 4 & & 5.4 & 3 & & 930 & 95.3 & 028 & 956 & 95.3 & 959 & 945 & & & 942 & 8 & 7.5 & & 34 & 87.5 & 01 & 4 \\
\hline 5 & & 42 & 93 & 7.4 & & 97.1 & 980 & 97.4 & 97.1 & 97.1 & 98.5 & & & 96.5 & $0=$ & 90.7 & & 85.1 & 90.1 & & 5 \\
\hline 6 & & 24 & 6.4 & 48 & 30 & & 980 & 99.7 & 99.4 & 99.4 & 98.5 & & & 98.3 & $0: 0$ & & & 869 & 90.7 & & 8 \\
\hline 7 & & & 8.3 & 6.4 & 2.1 & 2.1 & & 983 & 980 & & 988 & & & & & & & & 90.4 & & 7 \\
\hline 8 & & & 6.4 & 45 & 27 & 0.3 & 1.8 & & 99.7 & 99.7 & 988 & & & 98.5 & 962 & 210 & & & 91.0 & & 8 \\
\hline 9 & & 24 & 6.7 & 48 & 30 & 0.6 & 2.1 & 0.3 & & 98.4 & 98.5 & 97.4 & $9 / . T$ & 98.3 & 959 & 213 & 90.7 & 869 & 90.7 & & 9 \\
\hline 10 & & 24 & 6.7 & 42 & 30 & 06 & 2.1 & 0.3 & 0.6 & & 96.5 & 97.4 & 97.1 & 98.3 & 959 & 91.3 & 90.7 & 869 & 90.7 & & 10 \\
\hline 11 & 18 & 3.3 & 7.7 & 58 & 1.5 & 1.5 & 12 & 12 & 1.5 & 1.5 & & 98.3 & 98.5 & 97.4 & 968 & 91.5 & 910 & 866 & 910 & & 11 \\
\hline 12 & & 39 & 90 & 70 & 27 & 27 & 1.8 & 24 & 27 & 27 & 1.8 & & 98.5 & 96.8 & 96.8 & 910 & 90.1 & 85.4 & 90.1 & 962 & 12 \\
\hline 13 & 1.8 & 36 & 83 & 6.7 & 24 & 24 & 1.5 & 2.1 & 24 & 24 & 1.5 & 1.5 & & 97.1 & 97.7 & 90.7 & 90.1 & 85.7 & 90.1 & 96.5 & 13 \\
\hline 14 & & 30 & 80 & 6.1 & 36 & 1.8 & 27 & 1.5 & 1.8 & 1.8 & 27 & 3.3 & 30 & & 95.3 & 90.7 & 90.1 & 86.3 & 90.1 & 959 & 14 \\
\hline 15 & 3 & 5.5 & 03 & 8.7 & 36 & 42 & 33 & 39 & 42 & 42 & 3.3 & 33 & 24 & 48 & & 90.1 & 89.5 & 85.4 & 89.8 & 3 & 15 \\
\hline 16 & & 6 & 16.1 & 0 & 102 & 9.5 & 9 & 92 & 9.5 & 9.5 & 92 & 99 & 10.3 & 102 & 109 & & 97.7 & 90.1 & 97.1 & 2 & 16 \\
\hline 17 & 10.5 & 122 & 16.1 & 139 & 109 & 10.1 & 10.5 & 9.8 & 102 & 102 & 98 & 109 & 109 & 10.8 & 11.6 & 24 & & 90.1 & 98.8 & 936 & 17 \\
\hline 18 & 15.1 & 170 & 21.0 & 19.2 & 17.1 & 147 & 159 & 144 & 147 & 147 & 15.1 & 16.7 & 16.3 & 15.4 & 16.7 & 108 & 10.7 & & 89.5 & 886 & 18 \\
\hline 19 & 10.5 & 122 & 16.1 & 139 & 10.8 & 10.1 & 10.5 & 98 & 10.1 & 10.1 & 98 & 10.8 & 109 & 108 & 11.2 & 30 & 1.2 & 11.4 & & 936 & 19 \\
\hline \multirow[t]{2}{*}{20} & 33 & 48 & 100 & 80 & 42 & 36 & 3.3 & 3.3 & 36 & 36 & 3.3 & 39 & 36 & 42 & 49 & 62 & 6.8 & 126 & 68 & & 20 \\
\hline & 1 & 2 & 3 & 4 & 5 & 6 & 7 & 8 & 9 & 10 & 11 & 12 & 13 & 14 & 15 & 16 & 17 & 18 & 19 & 20 & \\
\hline
\end{tabular}

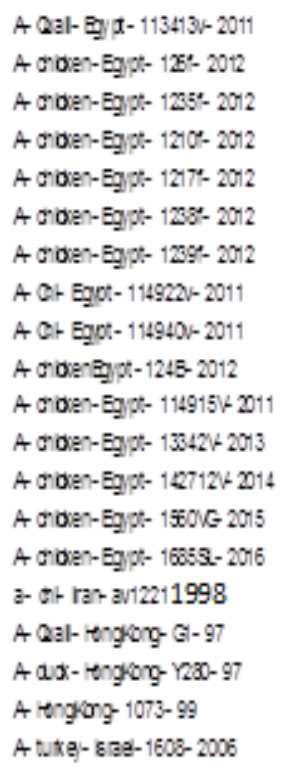

Figure 3: The partial HA gene of six $\mathrm{H9}$ nucleotide identities and divergence of Egyptian $\mathrm{H9}$ isolates (Sharkia Governorate, 2012) in comparison to other selected field and vaccinal strains on Genbank. 
On comparison with vaccinal strain, HA gene of the six Egyptian H9 AIV isolates in our study identity was 85.7-91.3 with Gallimune 208 (A/chicken/Iran/Av1221/1998) and 93.6-99.4 with ME FLUVAC H9 (A/chicken/Egypt/114940v/NLQP/2011).

Sequencing results revealed $85.7-90.7 \%$ homology of $\mathrm{H} 9$ gene with the isolate (A/Quail/Hong Kong/G1/97). Also, shared81.9-86.9\% with the isolate (A/Duck/Hong Kong/Y280/97). And shared
85.7- 90.7\% with the isolate (A/Hong Kong/1073/99). And shared 90.7- 96.8\% with the isolate (A/Turkey/Israel/1608/2006).

\section{Phylogenetic analysis}

The phylogenetic analysis for HA gene of the Six H9 AIV isolates showed the placement of the Egyptian viruses within the same lineage of $\mathrm{H} 9 \mathrm{~N} 2$ viruses that circulated in the region from 2006 especially with the Israeli strains of G1/97 lineage and other strains that circulating in the Middle East (Figure 4).

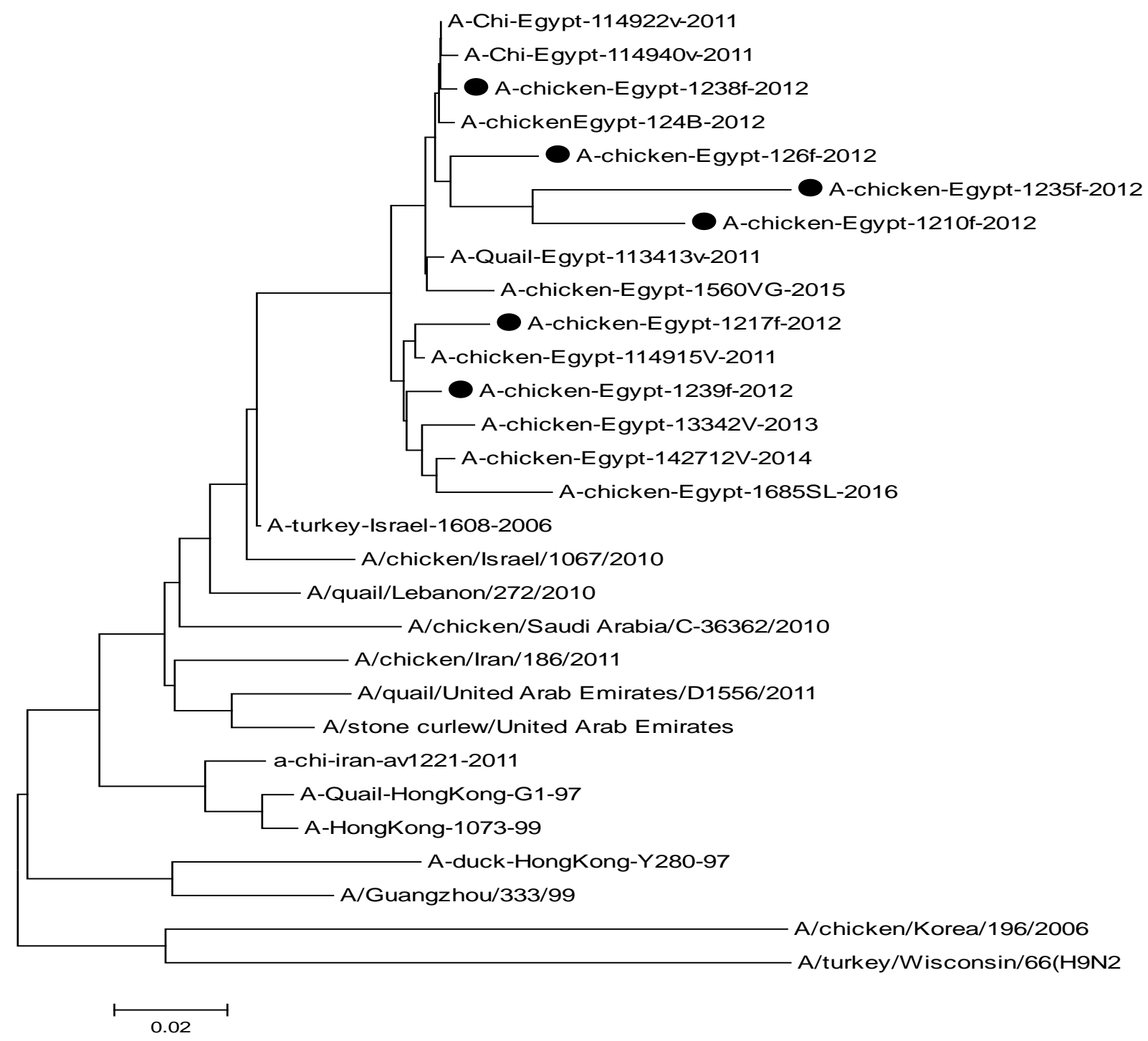

Figure 4: Phylogenetic analysis of $\mathrm{H} 9$ gene nucleotide sequences of AIV isolates from Sharkia Governorate, Egypt and other sequences available in GenBank for field and vaccinal $\mathbf{H 9}$ viruses. The tree was constructed via multiple alignments of 343-bp nucleotide sequence of HA gene using the neighbor-joining method and the Kimura-2-parameter models in MEGA7.Isolates in this study are marked with solid circle. 


\section{Discussion}

In the Middle East AIV- H9N2 has been recorded for several years, indicating additional risk factors to the poultry industry. Although H9N2 viruses are characterized as LPAI viruses, they may be isolated from flocks with high morbidity and mortality especially in disease complex. It is a major concern that spread of H9N2 in Egypt can negatively affect poultry health overall and increase the risk of H5N1 HPAI which is already endemic $[17,18]$. We succeeded to isolate LPAI H9 virus from different chicken breeds and ages in Sharkia Governorate. Identification and subtyping of the isolates by HA, HI tests and rRT-PCR were carried out. Sequencing of the HA gene to identify the changes in the genomic composition of our isolates was done. A comparison with some of both nationally and internationally published AI H9 viruses as well as vaccinal strain was carried out.

Low pathogenic AI virus infections are often unapparent and when present can be confused with other condition. However, some studies on the pathogenesis of H9N2 LPAI viruses revealed that diverse clinical syndromes of varying severity depending on co-infection with immunosuppressive agents could be observed [4,5].

The present results revealed that the frequently observed clinical signs among examined broiler flocks were respiratory signs including sneezing, coughing, nasal and ocular discharges with reduction in feed consumption. Diarrhea and facial edema were observed. While, examined layer flocks showed clinical signs in the form of depression, somnolence, and losses of appetite with drop in egg production and may accompanied with mild respiratory signs and periorbital edema. Similar clinical signs in H9N2 infected flocks were reported by other studies [19-21].

However, the results pointed out that, H9 avian influenza virus was also detected in two clinically healthy chicken flocks with a history of no mortality during routine surveillance programs for $\mathrm{H} 5 \mathrm{~N} 1$ infections. It may reflect the low pathogenic nature of the virus, which permits the silent spread of such viruses in apparently healthy commercial chickens.
Uncomplicated H9 virus infection was coincided with that reported by many authors [22-24].

The increased pathogenicity of $\mathrm{H} 9$ infection could be explained by various hypotheses. Theses hypotheses are: secretion of trypsinlike proteases by Bacteria [25], stimulation of host cells to produce or secrete more protease, destruction of endogenous cell protease inhibitors [26], and suppression of immune system due to stress by bacterial infection [5].

Consequently, the mortality rates varied according to the associated disease condition. They ranged from $0.5 \%$ to $70 \%$ in the affected broiler flocks. Drop in egg production was ranged from $30 \%$ to $70 \%$. Based on the discrepancies between the high mortality in the field and the low pathogenicity of the H9N2 strains in the laboratory conditions, it is suggested that concurrent bacterial and viral infection caused severe mortality to $70 \%$ in one flock which has mixed H9 \& IBV infections beside possibility of concurrent MG and $E$. coli field infections and egg drop to $70 \%$ in other flock has mixed H9 \& NDV infections. Similar findings were previously reported [27-30]

On necropsy, the examined broiler flocks had severe tracheitis, congestion of lungs and kidney were swollen with urate deposit as well as pericarditis, perihepatitis, peritonitis and air-sacculitis. The most severe cases had fibrinonecrotic caeous cast at the tracheal bifurcation, which extended into the primary and secondary bronchi in dead birds that were suffering from respiratory signs during H9N2 outbreak. Many authors recorded comparable gross lesions in complicated $\mathrm{H} 9$ virus infections [31-33]. Cast formation in the tracheal bifurcation is one of the well-Known lesions in Infectious bronchitis cases. However, tubular cast formation extending to the lower bronchi for the first time defined by Nili and Asasi, [34], as the most frequently observed lesion in broiler chickens suffering from H9N2 AI virus. However, this conclusion could be collapsed especially they used undefined filtered $(0.45 \mu \mathrm{m}$ filter $)$ tracheal washing of field affected birds with both MG and IBV but could be helpful only in anticipation of $\mathrm{H} 9$ presence in the complex. 
Virus isolation allows for the biological characterization of the virus as well as allowing for full sequence analysis [35, 36].

In this study virus isolation was carried out via inoculation in commercial ECE. Variable embryo mortality and lesions are comparable with the viral contents of each inoculum either in single or mixed infections. Similarly, AI type A (H5 and H9 subtypes), NDV and IBV viruses induced embryo death and lesions [37, 38].

In this study, the occurrence of avian influenza in chickens using $\mathrm{HI}$ test was 40.47\%. Subtyping for H9 and H5 subtypes has been done by specific antisera. The result was positive for H9 by percentage of $30.95 \%$ and for $\mathrm{H} 5$ by percentage of $9.52 \%$. These results are inconsistency with that of Awad et al. [18] who recorded comparable percentage of $\mathrm{AI} 42.22 \%$ and $\mathrm{H} 9$ virus was higher than H5 with percentage of $28.88 \%$ and $13.33 \%$, respectively. Moreover, NDV was detected in our study using HI test in $23.80 \%$ of the examined samples. These results are close to recent RLQP [39] investigations, who reported that the incidence of NDV was $20.5 \%$. The report also included co circulation of $\mathrm{H} 9 \mathrm{~N} 2$ with $17.5 \%$.

The selected seven AIV isolates representing broiler and layer flocks were confirmed by rRT-PCR using primers and probes specific for Matrix gene, $\mathrm{H} 9$ gene, H5 gene and $\mathrm{H} 7$ gene. Seven isolates were positive for $M$. gene and 6 isolates were positive for $\mathrm{H} 9$ gene, negative for $\mathrm{H} 5$ and $\mathrm{H} 7$ genes. The last isolate was positive for H5 gene, negative for $\mathrm{H} 9$ and $\mathrm{H} 7$ genes.

Partial sequence analysis of HA revealed that the HA genes from six isolates share similarity $91.3-98 \%$ with each other. They showed similarities with A/Quail/Egypt/113413v/2011 of 93.3- 99.1\%. The percent of identity was $92.7-99.7 \%$ with Egyptian strains of 2011, 93.6-99.4\% with Egyptian strain of 2012 and $92.7-98.5 \%$ with Egyptian strain of 2013. Also, they shared similarity $81.9-96.8 \%$ with other published sequences on Genbank. These results are closely similar to the previously published findings by Awad et al. [18] who reported that the similarity of the nucleotide sequence of his
Egyptian field H9 AIV isolate with the same strains was $83.8-95.7 \%$.

Recent H9N2 viruses have an HA cleavage site with dibasic (R-S-S-R) or tribasic (R-SK/R-R) motifs [40, 41, $42-43$ ] resembling the minimal furin motif $\mathrm{R}-\mathrm{X}-\mathrm{R} / \mathrm{K}-\mathrm{R}$. These viruses are of lower pathogenicity in birds, but appropriate mutations could alter the HA cleavage site to recognize by furin. In turn potentially results in HPAIV [44]. Therefore, we are interested in sequence analysis of this region.

The deduced amino acid sequences of the six field $\mathrm{H} 9$ isolates revealed that the HA cleavage site motif sequence is PARSSR/ GLF, a characteristic feature of low pathogenic [45], which could explain the isolation of H9 AIV from two apparently healthy broiler and layer flocks in this study. This motif is seen in other Asian H9N2 viruses including those from Japan, Iran, Pakistan, Saudi Arabia, Israel and Hong Kong [46, 22]. However, the presence of this particular motif also emphasizes that these viruses have potential to become pathogenic, should they acquire any further nucleotide substitutions in the HA-connecting peptide region to produce the basic motif required for highly pathogenic viruses [22]

Although, the six H9 viruses were isolated within one year, the amino acid sequence analysis revealed (1-15) substitutions suggesting a beginning of antigenic drift. This may result in a virus able to escape from host immune system [47].

Based on phylogenetic analysis of the HA gene of H9N2 viruses, there are, so far, two major genetic lineages: the North American and Eurasian lineages [48]. In the later, several sublineages have been distinguished: the G1like sub lineages was established in the Middle East and on the Indian subcontinent in the 1990s while other sublineages (Y280 and CK/ bei- like) circulate mainly in countries of the Far East [49].

The phylogenetic analysis for HA gene of the Six H9 AIV isolates showed the placement of the Egyptian viruses within the same lineage of $\mathrm{H} 9 \mathrm{~N} 2$ viruses that circulated in the region from 2006 especially with the recent Israeli strains of G1-like lineage. The same 
results were obtained by other studies $[7,8$, 20,50-53]. Phylogenetic analysis also showed sub-clustering of the six $\mathrm{H} 9$ isolates with the Egyptian sequences, pointing to a minor evolution during the past 2 years [52].

\section{Conclusion}

It could be concluded from the presented study that low pathogenic AIV H9N2 is circulating along Sharkia Governorate in both layer and broiler chickens. The H9N2 virus could be isolated from both clinically healthy as well as severe disease conditions in broiler and layer chickens. Also, concurrent viral and bacterial infection with NDV, IBV, MG and $E$. coli can exacerbate the disease condition. In addition to the circulating H9N2 AIV genetic analysis pointing to a minor evolution of H9N2 viruses. But at the same time the cocirculation of H5 \& H9 subtypes of AIV could be a risk for emergence of new AI viruses.

\section{Acknowledgments}

Special thanks to Dr. Shimaa Galal Mansour, Lecturer of Virology, Faculty of Vet. Medicine, Zagazig University for her valuable help.

\section{Conflict of interest}

None of the authors have any conflict of interest.

\section{References}

[1] El-Nagar, A. and Ibrahim, A. (2007): Case study of the Egyptian poultry sector. World J.Poult.Sci; 61 (3):491-514.

[2] Eid, A.M. (2015): Studies on viral respiratory problems prevalent in broiler chickens.M.Sc. Thesis. Beni-Suef University, Beni-Suef, Egypt.pg. 249.

[3] OIE Terrestrial Manual (2014): Chapter 2.3.4: Avian influenza. Manual of Diagnostic Tests and Vaccines for Terrestrial Animals. www.oie.int.

[4] Bano, S.; Naeem, K. and Malik, S.A. (2003): Evaluation of pathogenic potential of Avian Influenza virus serotype H9N2 in chickens. Avian Dis.; 47, 817-822.

[5] Kishida, N.; Sakoda, Y.; Eto, M.; Sunaga, Y. and Kida, H. (2004): Co-infection of Staphyloccocus aureus or Haemophilus paragallinarum exacerbates $\mathrm{H} 9 \mathrm{~N} 2$ influenza A virus infection in chickens. Archives of Virol.; 149, 2095-2104.

[6] Kim, J.A.; Cho, S.H.; Kim, H.S. and Seo, S.H. (2006): H9N2 influenza viruses isolated from poultry in Korean live bird markets continuously evolve and cause the severe clinical signs in layers. Veterinary Microbiol.; 118, 169-176.

[7] El-Zoghby, E.F.; Arafa, A.S.; Hassan, M.K.; Aly, M.M.; selim, A.; Kilany, W.H.; selim, U.; Nasef, S.; Aggor, M.G.; Abdelwahab, E.M. and Hafez. H.M. (2012): Isolation of H9N2 avian influenza virus from bobwhite quail (Colinus virginianus) in Egypt. Arch. Virol; 157, 1167-1172.

[8] Monne, I.; Hussein, H.A.; Fusaro, A.; Valastro, V.; Hamoud, M.M.; Khalefa, R.A.; Dardir, S.N.; Radwan, M.I.; Capua, Ilaria and Cattoli, G. (2013): H9N2 influenza A virus circulates in $\mathrm{H} 5 \mathrm{~N} 1$ endemically infected poultry population in Egypt. Influenza and Other Respiratory Viruses; 7 (3), 240-243.

[9] OIE Terrestrial Manual (2009): Chapter 2.3.4: Avian influenza. [Adopted by world Assemply of Delegates of the OIE in May 2009]. Available from: http:// www. oie.int/ fr/normes/ mmanual/ 2008/pdf/ 2.03.04 AI.pdf.

[10] WHO/CDC/CSR/NCS/2002: WHO manual on Animal influenza diagnosis and surveillance. http://whqlibdoc.who.int/hq/2002/WHO_ CDS_CSR_NCS_2002.5.pdf

[11] OIE Terrestrial Manual (2014): Chapter 2.3.4: Avian influenza. Manual of Diagnostic Tests and Vaccines for Terrestrial Animals. www.oie.int.

[12] Spackman, E.; Senne, D.A.; Myers, T.J.; Bulaga, L.L.; Garber, L.P.; Perdue M.L.; Lohman, K.; Daum, L.T. and Suarez, D.L. (2002): Development of a real-time reverse transcriptase PCR assay for type A influenza virus and the avian $\mathrm{H} 5$ and H7 hemagglutinin subtypes. J. Clin. Microbiol; 40, 3256-3260.

[13] Ben Shabat, M.; Meir, R.; Haddas, R.; Lapin, E.; Shkoda, I.; Raibstein, I.; Perk, S. and Davidson, I. (2010): Development 
of a real-time TaqMan RT-PCR assay for the detection of H9N2 avian influenza viruses. Journal of Virological Methods; $16872-77$.

[14] Slomka, M.J.; Pavlidis, T.; Banks, J.; Shell, W.; Mcnally, A.; Essen, S. and Brown, I.H. (2007): Validated H5 Eurasian real-time reverse transcriptasepolymerase chain reaction and its application in H5N1 outbreaks in 20052006. Avian Dis; 51, 373-377.

[15] Monne, I.; Ormelli, S.; Salviato, A.; De Battisti, C.; Bettini, F.; Salomoni, A.; Drago, A.; Zecchin, B.; Capua, I. and Cattoli, G. (2008): Development and validation of a one-step real-time PCR assay for simultaneous detection of subtype $\mathrm{H} 5, \mathrm{H} 7$, and $\mathrm{H} 9$ avian influenza viruses. J. Clin. Microbiol; 46, 17691773.

[16] Tamura, K.; Stecher, G.;Peterson, D.; Filipski, A and Kumar, S.;

MEGA6 (2013): Molecular Evolutionary Genetics Analysis version 7.0. Mol. Biol. Evol. 30:2725-2729.

[17] Park, K.G.; Kwon, H. I.; Song, M. S.; Noriel, P.; Pascua, Q.; Baek, Y.H.; Lee, J.H.; Jang, H. L.; Lim, J. Y.; Mo, I. P.; Moon, H. J.; Kim, C. J.; Choi, Y.K. and Gen, J. (2011): Rapid evolution of lowpathogenic H9N2 avian influenza viruses following poultry vaccination programmers. Virol; 92, 36-50.

[18] Awad, A.M.; Arafa, A.S. and Hagag, Sahar, Y. (2013): Incidence of Avian Influenza among Commercial and Native Breeds In West Delta Region. Alexandria Journal of Veterinary Sc; 39: 31-39.

[19] Capua, Ilaria and Terregino, C. (2009): clinical traits and pathology of avian influenza infections, Guidelines for farm visit and Differential Diagnosis in Avian Influenza and Newcastle Disease ed. Capaua, Ilaria and Alexander, D.J. eds springer-Verlag Italia pp. 45-72.

[20] Abdel-Moneim, A.S.; Afifi, M.A. and ElKady, M.A. (2012): Isolation and mutation trend analysis of influenza A virus subtype H9N2 in Egypt. Virology $\mathrm{J} ;$ 9:173.

[21] Naeem, K.; Ullah, A.; Manvell, R.J. and Alexander, D.J. (1999): Avian influenza A subtype H9N2 in poultry in Pakistan. Vet.Rec; 145:560.

[22] Aamir, U.B.; Wernery, U.; Ilyushina, N. and Webster, R.G. (2007): Characterization of avian H9N2 influenza viruses from United Arab Emirates 2000 to 2003. Virol; 361, 4555.

[23] Naeem, K.; Siddique, N.; Ayaz, M. and Jalalee, M. A. (2007): Avian influenza in Pakistan: outbreaks of low- and highpathogenicity avian influenza in Pakistan during 2003-2006. Avian Dis; 51(1 Suppl.): 189-193.

[24] Perk, S.; Golender, N.; Banet, C.; Shihmanter, E.; Pirak, M.; Tendler, Y.; Lipkind, Y. and Panshin, A. (2009): Phylogenetic analysis of hemagglutinin, neuraminidase, and nucleoprotein genes of H9N2 avian influenza viruses isolated in Israel during the 2000-2005 epizootic. Comparative Immunol. Microbiol. Infectious Dis; 32:221-238.

[25] Tashiro, M.; Ciborowski, P.; KlenK, H.D.; Pulverer, G. and Rott, R. (1987): Role of Staphylococcus protease in the development of influenza pneumonia. Nature; 325:536-537.

[26] Mancini, D.A.P.; Mendonca, R.M.Z.; Dias, A.L.F.; Mendonca, R.Z. and Pinto, J.R. (2005): Co-infection between influenza virus and flagellated bacteria. Rev Inst Meb Trop Sao Paulo; 47:275280.

[27] Naeem, K.; Naurin, M.; Rashid, S. and Bano, S. (2003): Seroprevalence of avian influenza virus and its relationship with increased mortality and decreased egg production. Avian Pathol; 32 (3): 285289.

[28] Vasfi Marandi, M. and BozorgmehriFard, M.H. (2002): Isolation of H9N2 Sub-type of Avian Influenza viruses during an outbreak in Iran. Iranian Biomedical J; 6, 13-17. 
[29] Know, H.J.; Cho, S.H.; Kim, M.C.; Ahn, Y.J. and Kim, S.J. (2006): Molecular epizootiology of recurrent low pathogenic avian influenza by $\mathrm{H} 9 \mathrm{~N} 2$ subtype virus in Korea. Avian Pathol; 35(4), 309-315.

[30] Toroghi, R. and Momayez, R. (2006): Biological and molecular characterization of Avian Influenza virus (H9N2) Isolates from Iran. Acta Virol; 50:163-8.

[31] Nili, H. and Asasi, K. (2002): Natural cases and experimental study of H9N2. Avian Pathol; 31, 247-252.

[32] Seifi, S.; Asasi, K. and Mohammadi, A. (2010): natural co-infection caused by avian influenza (H9 subtype) and infection bronchitis viruses in broiler chicken. Veterinarski Arhiv; 80(2), 269281, 2010.

[33] Swayne, D.E. and Halvorson, D.A. (2003): Avian influenza: cited after Saif, Y.M.; Barnes, H.J.; Gilson, J.R.; Fadly , A.M.; Mc-Dougald, I.R. and Swayne, D.E. $11^{\text {th }}$ ed. of Disease of poultry. Iowa State University Press, Iowa, USA, 135160.

[34] Nili, H. and Asasi, K. (2003): Avian Influenza (H9N2) outbreak in Iran. Avian Dis; 47, 828-831.

[35] Suarez, D.L.; Das, A. and Ellis, E (2007): Review of Rapid Molecular Diagnostic Tools for Avian Influenza Virus. Avian Diseases: March 2007, Vol. 51, No. s1, pp. 201-208.

[36] OIE, Manual, (2008): Avian influenza. Manual of Diagnostic tests and vaccines for terrestrial animals. Chapter 2.3.4.

[37] Cunningham, C.H. and Dardiry, A.H.E. (1948): Distribution of the virus of infectious bronchitis of chickens in embryonated chicken eggs. Cornell Vet; 38: 381-388.

[38] Haghighat-Jahromi, M.; Asasi, K.; Nili, H.; Dadras, H.; and Shooshtari, A.H. (2008): Co-infection of avian influenza virus (H9N2 subtype) with infectious bronchitis live vaccine. Arch Virol; 153: 651-655.
[39] RLQP. (2012): Field and laboratory study on respiratory disease complex in commercial animal product sector- 2012. RLQP, Animal Health Research Institute, Ministry of Agriculture and Land Reclamation, Dokii, Egypt.

[40] Guo, Y.J.; Krauss, S.; Senne, D.A.; Mo, I.P.; Lo, K.S.; Xiong, X.P.; Norwood, M.; Shortridge, K.F.; Webster, R.G. and Guan, Y. (2000): Characterization of the pathogenicity of members of the newly established H9N2 influenza virus lineages in Asia. Virol; 267, 279-288.

[41] Perk, S.; Banet, C.; Shihmanter, E.; Pokamunski, S.; Pirak, M.; Lipkind, Y. and Panshin, A. (2006-a): Genetic characterization of $\mathrm{H} 9 \mathrm{~N} 2$ influenza viruses circulated in poultry population in Israel. Comparative Immunol. Microbiol. Infectious Dis; 29, 207-223.

[42] Perk, S.; Panshin, A.; Shihmanter, E.; Gissin, I.; Pokamunski, S.; Pirak, M. and Lipkind, Y. (2006-b): Ecology and molecular epidemiology of H9N2 avian influenza viruses isolated in Israel during 2000-2004 epizootic. Dev Biol (Basel); 124, 201-209.

[43] Xu, K. M.; Smith, G. J.; Bahl, J.; Duan, L.; Tai, H.; Vijaykrishna, D.; Wang, J.; Zhang, J. X.; Li, K. S.; Fan, X. H.; Webster, R. G.; Chen, H.; Peiris, J. S. M. and Guan. Y. (2007): The genesis and evolution of H9N2 influenza viruses in poultry from Southern China, 2000 to 2005. J. Virol; 81:10389-10401.

[44] Vey, M.; Orlich, M.;Adler, S.; Klenk, H.; Rott, R. and Garten, W. (1992): Hemagglutinin activation of pathogenic avian influenza viruses of serotype $\mathrm{H} 7$ requires the protease recognition motif RX- K/R-R. Virol; 188(1):408-413.

[45] Perdue, M.L.; Garcia, M.; Senne, D. and Fraire, M. (1997): Virulence associated sequence duplication at the hemagglutinin cleavage site of avian influenza viruses. Virus Res; 49, 173186.

[46] Kawaoka, Y. and Webster, R.G. (1998): Sequence requirements for cleavage activation of influenza virus 
hemagglutinin expressed in mammalian cells. Proc.Nalt. Acad Sci USA; 85(2):324-328.

[47] Swayne, D.E. (2009): Avian influenza vaccines and therapies for poultry, Comparative Immunology, Microbiology and infectious diseases; 32:351-363.

[48] Banks, J.; Speidel, E.C.; Harris, P.A. and Alexander, D.J. (2000): Phylogenetic analysis of influenza A viruses of $\mathrm{H} 9$ haemagglutinin subtype. Avian Pathol; 29:353-360.

[49] Shahsavandi, S.; Salmanian, A.H.; Ghorashi, S.A.; Masoudi, S.; Fotouhi, F. and Ebrahimi, M.M. (2011): Development of rHA1- ELISA for specific and sensitive detection of $\mathrm{H} 9$ subtype influenza virus. J.Virol.Methods; 171: 260-263.

[50] Arafa, A.S.; Hagag, N.; Erfan, A.; Mady, W.; El- Husseiny, M.; Adel, A. and Nasef, S. (2012a): Complete genome characterization of avian influenza virus subtype H9N2 from a commercial quail flock in Egypt. Virus Genes; DOI 10.1007/s11262-012-0775-0.

[51]Arafa, A.S.; Hagag, N.; Yehia, N.; Zanaty, A.M.; Naguib, M.M. and Nasef, S.A.(2012b) : Effect of co-circulation of highly pathogenic avian influenza $\mathrm{H} 5 \mathrm{~N} 1$ subtype with low pathogenic H9N2 subtype on the spread of infections. Avian Dis; 2012 Dec; 56(4 Suppl):849-57.

[52] Kayali, G.; Kandeil, A.; El-Shesheny, R.; Kayed, A.S.; Gomaa, M.M.; Maatouq, Asmaa, M.; Shehata, M.M.; Moatasim, Yassmin; Bagato, Ola ; Cai, Z.; Rubrum, A.; Kutkat, M.A.; McKenzie, P.P.; Webster, R.G.; Webby, R.J. and Ali, M.A.(2014): Active surveillance for Avian Influenza Virus, Egypt,20102012. Emerging Infectious Dis; Vol.20, No.4, April 2014.

[53] Ahmed, Zakia, A.M.; Hussein H.A. and Rohaim M.A. (2013): Efficacy of composting poultry mortality and farms wastes with mixed respiratory infection viruses H9N2 and NDV in Egypt. Global Veterinaria; 11(2): 177-185, 2013.

\footnotetext{
الملخص العربى

تواجد فيروس انفلونزا الطيور من نوع اتش 9 فى بداري التسمين والاجاج البياض بمحافظه الشرقيه

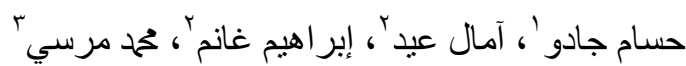

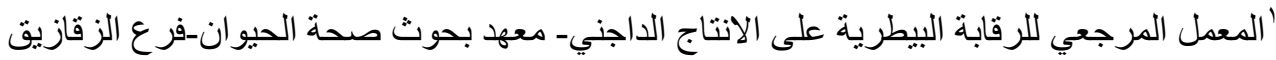

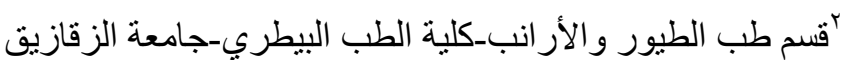$$
\text { "المعمل المرجعي للرقابة البيطرية على الانتاج الداجنيـ معهد بحوث صحة الحيوان-فرع الاسماعيلية }
$$

مرض انفلونزا الطيور من الامراض المعديه والذي يسبيه نوع من فيروسات الانفلونزا A. و وعلى الرغم من ان فيروس

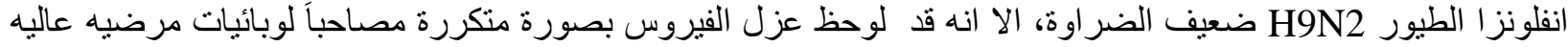

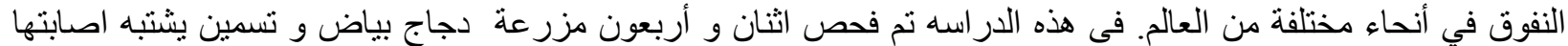

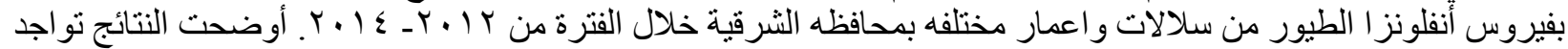

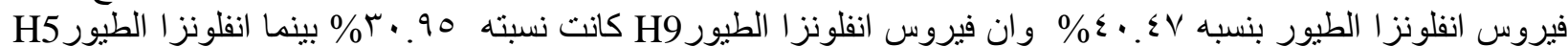

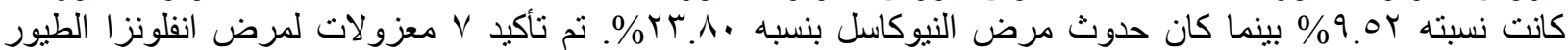

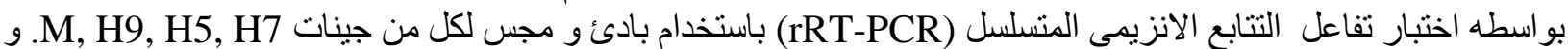

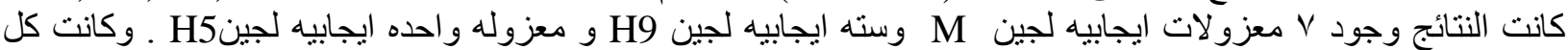

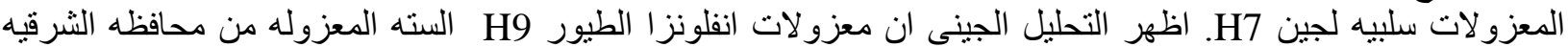

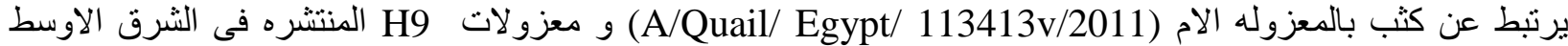

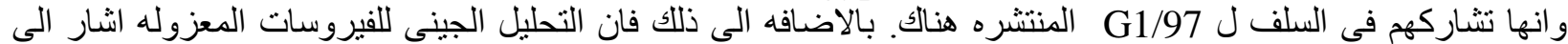

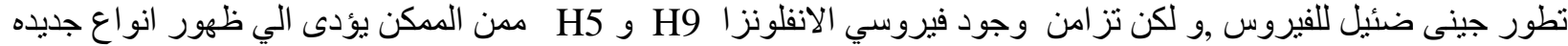

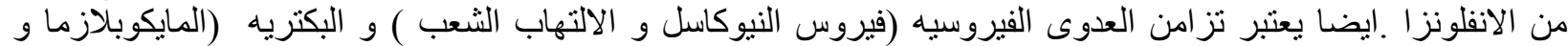

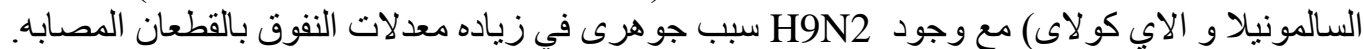

